\title{
Antioxidant and Apoptotic Effect of Muscari muscarimi, an Endemic Geophyte Species from Turkey
}

\author{
Cennet Ozay ${ }^{1, *}$, Ege Riza Karagur², Ramazan Mammadov ${ }^{3}$ and Hakan Akca ${ }^{2}$ \\ ${ }^{1}$ Izmir Katip Celebi University, Faculty of Pharmacy, Department of Basic Pharmaceutical Sciences, Izmir 35620, Turkey; ${ }^{2}$ Pamukkale \\ University, Faculty of Medicine, Department of Medical Genetics, Denizli 20070, Turkey; ${ }^{3}$ Muğla Sitkı Koçman University, Faculty of \\ Science, Department of Molecular Biology and Genetics, Muğla 48121, Turkey
}

Received: October 16, 2020; Revised: January 19, 2021; Accepted: January 28, 2021

\begin{abstract}
Muscari muscarimi Medik., which is an endangered and endemic geophyte species of Turkey, was studied for antioxidant, cytotoxic and apoptotic potentials. The antioxidant effect of the extracts (ethanol and methanol) provided from the flower and bulbs of M. muscarimi was tested through the antioxidant potency by phosphomolybdenum assay, the reducing power assay, metal chelating ability, nitric oxide scavenging and ABTS radical cation scavenging capability methods. Also, total flavonoid and saponin content of the extracts was specified. Cytotoxic activity of the extracts was assessed and screened against human MCF-7, HeLa and H1299 cancer cells. Terminal transferase dUTP nick end-labeling (TUNEL) assay was applied to cancer cells for the determination of the late apoptotic changes. Antioxidant potencies in bulb extracts were observed to be lower than the flower extracts. However, the cytotoxicity and TUNEL assay revealed that the bulb extracts exhibited more marked anticancer activity against H1299 cell line than the other cell lines. Based on the in vitro data, $M$. muscarimi warrants further studies to isolate novel compounds for chemotherapeutic use.
\end{abstract}

Keywords: Antioxidant activity, Apoptosis, Cancer cell lines, Muscari muscarimi, Turkey

\section{Introduction}

The use of plants as medicines has a history as old as mankind. Traditional medicinal plants have been used to cure several diseases for thousands of years in different parts of the World (Adebayo \& Krettli, 2011). Turkey is one of the most prominent floristic regions on the earth due to its geologic, topographic and climatic features. Floristic studies have shown that Turkey houses about 12000 plant taxa on its soils and more than 3000 taxa among them are endemic (Hoekstra et al., 2005). Geophytes are a considerable component of this generous biodiversity and include a lot of significant endangered and endemic species such as Muscari muscarimi Medik. The genus Muscari Mill. was formerly classified in the family Liliaceae but recently has been reclassified in the family Asparagaceae (Mulholland et al., 2013). The total number of Muscari species recorded in Turkish flora is approximately 39, and 24 of them (61.5\%) are endemic (Eker, 2019). M. muscarimi is a perennial bulbous plant known as 'misk sümbülü', growing in south-west Turkey. This endemic species is most fragrant species in the genus Muscari and has high ornamental potential. It bears fascinating dirty bluish-gray flowers that bloom between March and May each year. The indigenous populations of $M$. muscarimi, is critically affected by enhanced environmental impurity and urbanization (Ozel et al., 2015). It has been used in the folk medicine in Turkey. In addition to this, it has also been used as ornamental plants in gardens, dye and as food for animals and humans (Oztas et al., 2018). Some species of Muscari have been utilized in conventional medicine as hypoglycemic, diuretic, antirheumatic, antiverruca, antiallergic and expectorant (Kayıran \& Özkan, 2017, Loizzo et al., 2010). Different investigations have also been notified to the antioxidant, antimicrobial and anticancer effects of Muscari (Mammadov et al., 2012, Mammadov et al., 2016, Eroğlu Özkan et al., 2018).

Antioxidants preserve the cell constituents towards oxidative loss caused by free radicals. Phenolic compounds, alkaloids, terpenoids and other secondary metabolites present in plants are superb in antioxidative effects. Researchers have found out that many of these antioxidant components have anticancer, antiinflammatory, antimutagenic, antimicrobial and antiviral potentials (Shahidi \& Ambigaipalan, 2015). Muscari Mill. contains different phytochemicals with biological activities including homoisoflavonoids, glycosides and water-soluble polysaccharides (Urbancikova et al., 2002, Adinolfi et al., 1985). Lanosterol and tetranorlanosterol glycosides from Muscari paradoxum (bulbs) were assessed for their cytotoxic effect on HSC-2 cancer cells. Even though the tetranorlanostane glycosides did not display any cytotoxicity on HSC-2 cells, the lanostane glycosides exhibited high cytotoxic activity (Ori et al., 2003). It was reported that homoisoflavonoid compounds isolated from $M$. neglectum had antiinflammatory, estrogenic, antiestrogenic, anticancer and angioprotective bioactivities (Lim, 2014).

\footnotetext{
* Corresponding author e-mail: cennet.ozay@ikcu.edu.tr.
} 
Cancer is a fatal universal illness of these times and a crucial obstacle in the ever-increasing lifetime of affected inhabitants (Bray et al., 2018). Despite a general choice for cancer therapy, chemotherapy is restricted by drug resistance and noxious adverse effects (Hanahan \& Weinberg, 2011). Natural products can inhibit cancer and restrain tumor growth via cell fate pathways containing apoptosis (Fulda, 2010). Cancer cells are invulnerable to apoptosis owing to the activation of anti-apoptotic proteins or suppression of pro-apoptotic proteins (Pandey et al., 2016). In recent times, a lot of plant extracts or their isolated compounds have been evaluated for apoptotic effect, and several mechanisms of actions have been proposed for their toxicity against cancer cells. Hence, in this study, M. muscarimi, which is an endemic and endangered species, was assessed for cytotoxicity and possible apoptotic ability taking into consideration that there has been no paper about such activities previously. The antioxidant activity of $M$. muscarimi was investigated through mainly five methods, and its total flavonoid and saponin content was also determined.

\section{Materials and Methods}

\subsection{Plant material and extraction}

Approximately, $250 \mathrm{~g}$ of $M$. muscarimi were picked up in May 2013 from Antalya (900 m), located in the southern part of Turkey and identified by (Voucher No: RM1001) Dr. Ramazan Mammadov, Muğla Sitkı Koçman University, Turkey. The plant was divided into two parts as bulb and flowers and dried in shade at room temperature. The pulverised plant parts were separately subjected to solvent extraction in a shaker water bath with methanol and ethanol at $48-50^{\circ} \mathrm{C}$ for $6 \mathrm{~h}$. The extraction was repeated twice at the same condition. Then solvents were removed with a rotary evaporator (IKA RV, Germany), samples were lyophilised (Labconco FreeZone, USA). The crude samples were kept at $-20^{\circ} \mathrm{C}$ until needed (Ozay \& Mammadov, 2017).

\subsection{Total flavonoid and saponin contents}

The total amounts of flavonoid and saponin substances of the plant extracts were detected by using the aluminum chloride (Moreno et al., 2000) and vanillin-sulphuric acid (Hiai et al., 1976) colorimetric methods, respectively. These substances were expressed as quercetin (mg QEs/g) and quillaja (mg QAEs/g) equivalents, respectively.

\subsection{Antioxidant activity assays}

\subsubsection{Total antioxidant capacity (TAC)}

The phosphomolybdenum method was used to evaluate the TAC of the extracts. To keep it short, different extract solutions were mixed with the reagent solution and incubated at $95^{\circ} \mathrm{C}$ for $90 \mathrm{~min}$. The absorbance values were determined at a wavelength of $695 \mathrm{~nm}$ (Prieto et al., 1999). TAC is denoted as ascorbic acid (mg AEs/g) equivalents.

\subsubsection{Ferric reducing antioxidant power (FRAP) assay}

FRAP assay was applied as defined by Zengin et al., (2015). with small modifications. Extracts solutions were added to FRAP reagent which was mixed in advance. After measuring the absorbances at 593 nm, FRAP potential is denoted as Trolox (mg TEs/g extract) equivalents.

\subsubsection{Metal chelating activity}

Extracts solutions at different concentrations were added to $\mathrm{FeCl}_{2}$. The reaction that started directly after adding ferrozine was read at $562 \mathrm{~nm}$ after being left for 10 min left at $25^{\circ} \mathrm{C}$. Metal chelating effect is denoted as EDTA (mg EDTAEs/g extract) equivalents (Zengin et al., 2015).

\subsubsection{ABTS radical scavenging activity}

The scavenging activity towards ABTS (2,2 azino-bis (3-ethylbenzothiazloine-6-sulfonic acid)) radical was analyzed as described by Re et al., (1999) with slight modifications. Freshly prepared and diluted ABTS solution was joined in the extracts of $M$. muscarimi (20$1000 \mu \mathrm{g} / \mathrm{mL}$ ), and the absorbances were read after $30 \mathrm{~min}$ at $734 \mathrm{~nm}$. The outcomes were indicated as $\mathrm{IC}_{50}$.

\subsubsection{Nitric oxide (NO) scavenging activity}

NO was produced from sodium nitroprusside (SNP) which read as defined by Balakrishnan et al., (2009) in the Griess reaction. SNP $(5 \mathrm{mM})$ in PBS was incubated with several concentrations (20-1000 $\mu \mathrm{g} / \mathrm{ml})$ of the extracts, and the tubes were kept waiting for 3 hours at $25^{\circ} \mathrm{C}$. The absorbance value was determined at $546 \mathrm{~nm}$ wavelength. Ascorbic acid was employed as an antioxidant standard. The results were indicated as $\mathrm{IC}_{50}$.

\subsection{Cytotoxicity assay}

HeLa (cervix adenocarcinoma), MCF-7 (breast adenocarcinoma) and H1299 (non-small cell lung adenocarcinoma) human cancer cell lines were employed in this research. The cells were cultured in RPMI 1640 medium in a $\mathrm{CO}_{2}$ incubator. 24 hours incubation after seeding into 96 -well plates $\left(2 \times 10^{3}\right.$ cells/well), the medium was removed from the well leaving the adherent cells and cells were applied with extract for 72 hours in the range of $25-1000 \mu \mathrm{g} / \mathrm{mL}$. After time was up, cell viability was determined by using CytotoxGlo kit (Promega, USA), in accordance with the manufacturer's instructions. The percentage of cell viability was calculated relative to control cells. A plot of cell viability (\%) against concentration was created, and the concentration of the plant extract that decreased cell viability by $50 \%$ ( $\mathrm{IC}_{50}$ ) was calculated.

\subsection{TUNEL assay}

The apoptotic effects of $M$. muscarimi bulb extracts in HeLa, MCF-7 and H1299 cells were evaluated using the TUNEL assay. The cells were treated with $\mathrm{IC}_{50}$ values of each extract for $24 \mathrm{~h}$ at $37^{\circ} \mathrm{C}$. To determine cell death, the In Situ Cell Death Detection Kit (Millipore, USA) was used in accordance with the manufacturer's instructions. The TUNEL-stained apoptotic cells were visualized by use of a microscope and then counted. The data were expressed as a percentage of the area of TUNEL-positive cells in 10 random fields.

\subsection{Statistical analysis}

Statistical analysis was performed using the software SPSS version 22.0 program. Statistical significance was determined using the one-way ANOVA. Multiple group comparisons were analyzed with Tukey's multiple comparison test. Data were expressed as mean \pm standart error of three separate experiments. $p$ value of $<0.05$ was considered statistically significant. 


\section{Results}

\subsection{Antioxidant activity}

Antioxidant activity of the bulb and flowers of $M$. muscarimi was assayed by using FRAP, ABTS, NO, phosphomolybdenum and metal chelating assays. Also, total amounts of flavonoid and saponin substances of the extracts were calculated by using the aluminum chloride and vanillin-sulphuric acid assays, respectively. The outcomes of all these assays are presented in Tables 1 and 2. According to the data that were obtained, the highest total flavonoid content was found for the methanolic flower extract as $27.22 \mathrm{mg}$ QEs/g, while the highest total saponin content was detected for the methanolic bulb extract as $140.41 \mathrm{mg} \mathrm{QAEs/g}(p<0.05)$ (Table 1$)$. Flower methanolic extract had the highest ABTS (IC 50 value $=52.16 \mu \mathrm{g} / \mathrm{ml}$ ) and $\mathrm{NO}\left(\mathrm{IC}_{50}\right.$ value $=64.35 \mu \mathrm{g} / \mathrm{ml}$ ) radical scavenging activities $(p<0.05)$ followed by the flower ethanolic extract (Table 2). Likewise, the highest results of the FRAP, phosphomolybdenum and metal chelating assays for $M$. muscarimi were determined in the flower methanolic extract as $77.53 \mathrm{mg} \mathrm{TEs} / \mathrm{g}, 62.05 \mathrm{mg}$ AEs/g and $24.10 \mathrm{mg}$ EDTAEs/g extract, respectively.

Table 1. Total antioxidant capacity, total flavonoid and saponin contents of M. muscarimi extracts (mean $\pm \mathrm{SE}$ ).

\begin{tabular}{lllc}
\hline Extracts & TFC & TSC & TAC \\
\hline BE & $19.35 \pm 0.45^{\mathrm{b}}$ & $134.01 \pm 4.12^{\mathrm{a}}$ & $44.33 \pm 2.27^{\mathrm{b}}$ \\
BM & $15.33 \pm 0.63^{\mathrm{b}}$ & $140.41 \pm 4.35^{\mathrm{a}}$ & $47.24 \pm 2.41^{\mathrm{b}}$ \\
FE & $23.12 \pm 0.71^{\mathrm{a}}$ & $110.63 \pm 3.06^{\mathrm{c}}$ & $58.32 \pm 2.65^{\mathrm{a}}$ \\
FM & $27.22 \pm 0.75^{\mathrm{a}}$ & $128.17 \pm 3.52^{\mathrm{b}}$ & $62.05 \pm 2.73^{\mathrm{a}}$ \\
\hline
\end{tabular}

TFC (Total flavonoid content): quercetin equivalents (mg QEs/g). TSC (Total saponin content): quillaja equivalents (mg QEs/g). TAC (Total antioxidant capacity): ascorbic acid equivalents (mg AEs/g). BM/FM: Bulb/Flower Methanol, BE/FE: Bulb/Flower Ethanol. Different letters in the same column indicate a significant difference $(p<0.05)$

Table 2. Antioxidant activities of M. muscarimi extracts (mean \pm SE).

\begin{tabular}{lllll}
\hline Extracts & $\begin{array}{l}\text { ABTS } \\
\left(\mathrm{IC}_{50} \mu \mathrm{g} / \mathrm{mL}\right)\end{array}$ & $\begin{array}{l}\text { NO } \\
\left(\mathrm{IC}_{50} \mu \mathrm{g} / \mathrm{mL}\right)\end{array}$ & $\begin{array}{l}\text { FRAP assay } \\
(\mathrm{mg} \mathrm{TEs} / \mathrm{g})\end{array}$ & $\begin{array}{l}\text { Metal chelating } \\
\text { activity } \\
(\mathrm{mg} \\
\text { EDTAEs/g) }\end{array}$ \\
\hline BE & $63.29 \pm 1.24^{\mathrm{b}}$ & $76.14 \pm 1.55^{\mathrm{b}}$ & $58.24 \pm 0.30^{\mathrm{c}}$ & $12.16 \pm 0.04^{\mathrm{b}}$ \\
$\mathrm{BM}$ & $68.70 \pm 1.38^{\mathrm{a}}$ & $81.42 \pm 1.67^{\mathrm{a}}$ & $62.48 \pm 0.33^{\mathrm{c}}$ & $14.03 \pm 0.07^{\mathrm{b}}$ \\
FE & $55.01 \pm 0.17^{\mathrm{c}}$ & $72.21 \pm 1.01^{\mathrm{b}}$ & $71.02 \pm 1.54^{\mathrm{b}}$ & $17.85 \pm 0.15^{\mathrm{b}}$ \\
FM & $52.16 \pm 0.12^{\mathrm{c}}$ & $64.35 \pm 0.56^{\mathrm{c}}$ & $77.53 \pm 1.63^{\mathrm{a}}$ & $24.10 \pm 0.26^{\mathrm{a}}$ \\
Ascorbic & $08.11 \pm 0.03^{\mathrm{d}}$ & $19.02 \pm 0.05^{\mathrm{d}}$ & $\mathrm{nt}$ & $\mathrm{nt}$ \\
acid & & & & \\
\hline
\end{tabular}

BM/FM: Bulb/Flower Methanol; BE/FE: Bulb/Flower Ethanol, TEs: Trolox equivalents, EDTAEs: EDTA equivalents, nt: no tested. Different letters in the same column indicate a significant difference $(p<0.05)$

\subsection{Cytotoxic activity and TUNEL assay}

To evaluate the cytotoxic activity of the $M$. muscarimi bulb extracts at several concentrations $(25-1000 \mu \mathrm{g} / \mathrm{mL})$ towards MCF-7, HeLa and H1299 cancer cell lines for 72 h, CytotoxGlo assay was carried out. A decrease in viability in cancer cells was observed in a concentrationdependent manner $(p<0.05)$ (Fig. 1 and 2). The $\mathrm{IC}_{50}$ values $(\mu \mathrm{g} / \mathrm{mL})$ of ethanolic and methanolic bulb extracts in different cancer cell lines were tabulated (Table 3). Methanolic bulb extracts were found to have lower $\mathrm{IC}_{50}$ values in all cancer cells than ethanolic extracts. The $\mathrm{IC}_{50}$ values for the methanolic extract were $90.43,140.13$ and $58.20 \mu \mathrm{g} / \mathrm{mL}$ on MCF-7, HeLa and H1299 cells, respectively. The apoptosis-inducing potential of $M$. muscarimi bulb extract was evaluated in the cancer cell lines using the TUNEL assay after treatment with the extracts at their $\mathrm{IC}_{50}$ doses for $24 \mathrm{~h}$. A remarkable rise in apoptotic cells was noticed in the H1299 cells treated with methanolic bulb $(45.0 \pm 2.38 \%)$ and ethanolic bulb $(41.4 \pm$ $2.35 \%$ ) extracts, compared with the control $(p<0.05)$ (Fig. 3). Apoptotic cells in H1299 cells were shown in Fig. 4.

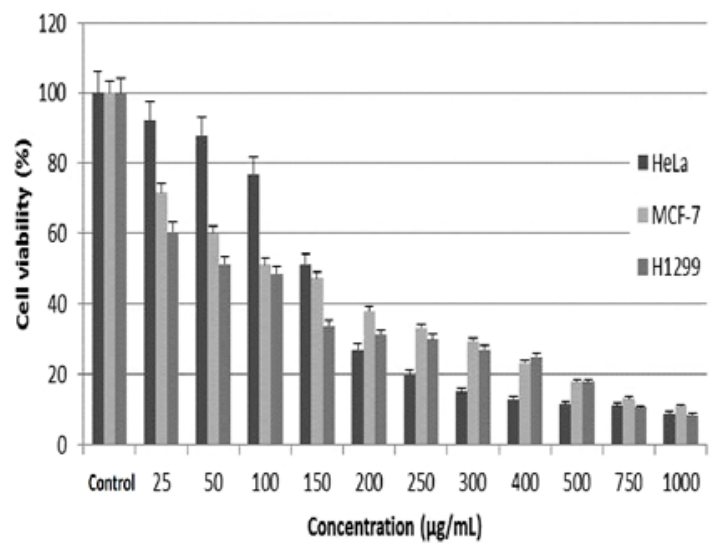

Figure 1. Cytotoxic activity of M. muscarimi ethanolic bulb extracts against different cancer cell lines. Data are presented as mean \pm SE.

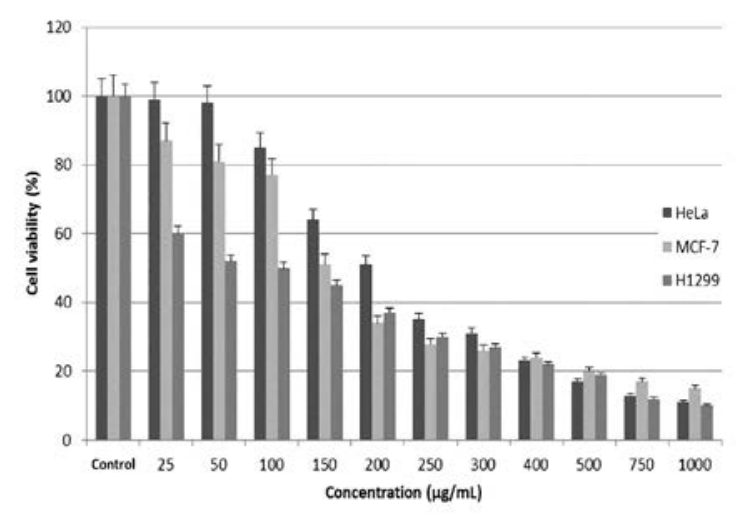

Figure 2. Cytotoxic activity of M. muscarimi methanolic bulb extracts against different cancer cell lines. Data are presented as mean \pm SE.

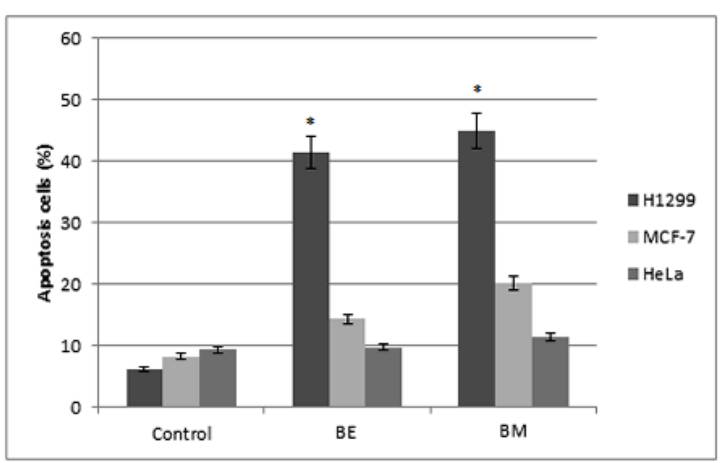

Figure 3. Apoptotic effects of $M$. muscarimi bulb extracts in different cancer cell lines. Data are presented as mean \pm SE. 


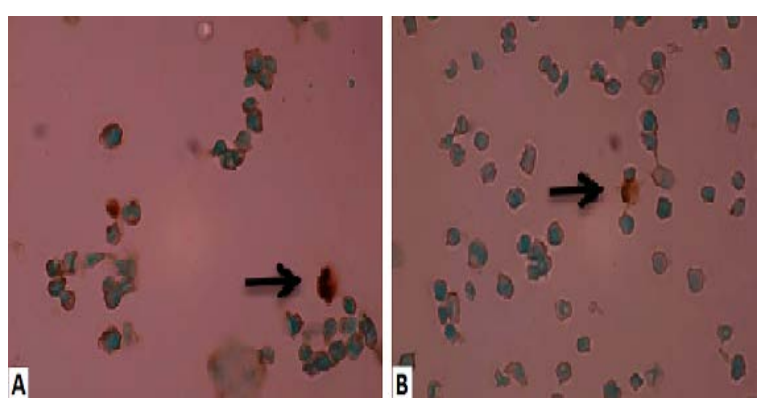

Figure 4. Apoptotic cells in H1299 cells treated by M. muscarimi bulb extracts (A: methanol, B: ethanol) using TUNEL assay. The arrows show the apoptotic cells.

Table 3. $\mathrm{IC}_{50}(\mu \mathrm{g} / \mathrm{mL})$ values of $M$. muscarimi in different cancer cell lines

\begin{tabular}{llll}
\hline Extracts & HeLa & MCF-7 & H1299 \\
\hline BE & $205.01 \pm 1.46$ & $135.08 \pm 1.28$ & $62.05 \pm 1.24$ \\
BM & $140.13 \pm 1.30$ & $90.43 \pm 1.26$ & $58.20 \pm 1.20$
\end{tabular}

BE: Bulb Ethanol, BM: Bulb Methanol. Data are presented as mean \pm SE.

\section{Discussion}

The plants extensively include substances that high antioxidant activity owing to the being of phenolic complexes particularly flavonoids (Tungmunnithum et al., 2018). Antioxidants were called as bioactive substances that prevent the generation of free radicals or neutralize free radicals in living organisms. To prevent oxidative degradation of food, some antioxidants called synthetic (BHT, BHA, etc.) are extensively used in the food industry, but these synthetic antioxidants are suspected of being responsible for tumorigenesis (Lourenço et al., 2019). Therefore, the improvement and usage of more powerful antioxidants from natural resource are needed.

In studies evaluating the antioxidant activity of $M$. muscarimi, two free radicals (NO and ABTS) were used, and the studies determined the rate at which these radicals are scavenged by the extracts. Transition metals act as a catalyst for lipid peroxidation. Therefore, chelating these metals is considered as an important antioxidant mechanism (Zengin \& Aktumsek, 2014). In this study using the phosphomolybdenum assay, FRAP assay and metal chelating activity, it was found that the flower extracts demonstrated higher antioxidant potency than the bulb extracts. We have previously published data representing the antioxidant activity of $M$. muscarimi using two assays namely, $\beta$-carotene/linoleic acid assay and DPPH assay and similarly, the flower extracts were detected to have higher antioxidant activity than the bulb extracts. Also, the highest total phenolic content was determined in the methanolic flower extract (38.13 mg GAEs/g) (Mammadov et al., 2016). In the current research, the highest total flavonoid content was determined in the methanolic flower extract as $27.22 \mathrm{mg}$ QEs/g. Therefore, the higher antioxidant activity of methanolic flower extract may be depending on its total phenolic and flavonoid contents.

To assess the cytotoxic activity of the extracts of $M$. muscarimi on the growth of HeLa, MCF-7 and H1299 cell lines, the bulb extracts were examined. The low cytotoxicity of the flower extracts has directed us to this choice (data not shown). Also, in our previous report, the brine shrimp lethality test results of the $M$. muscarimi extracts showed that the flower extracts were less cytotoxic than the bulb extracts (Mammadov et al., 2016).

Many phytochemicals are biologically active, and they may interact to protect against cancer. Flavonoids are quite strong antioxidants, which scavenge free radicals, prevent the progression of cancer and protect towards oxidative stress related diseases (Abotaleb et al., 2019, Vrancheva et al., 2020). Flavonoids demonstrate powerful anticancer potencies against different cancer cells, mediated through coordinating of primary signaling pathways involved in the migration and invasion of cancer cells and metastatic spread, plus increase apoptosis (Ravishankar et al., 2013). It was reported that the chemical components of the genus Muscari are homo-isoflavanones, flavonoids, glycosides, alkaloids and terpenoids (Urbancikova et al., 2002; Lim, 2014). It has been shown that $M$. racemosum homoisoflavonoids have antimutagenic features and may be important for the prevention from cancer (Miadokova et al., 2002). In the current study, we found that the bulb extracts had higher saponin content than the flower extracts. Cytotoxicity of the bulb extracts containing a high amount of saponin was higher than the flower extracts. Studies in recent years have stated that saponins indicate remarkable anticancer activity, like antiproliferation via mechanisms that contain induction of apoptosis (Man et al., 2010). Not surprisingly, the percentages of TUNEL-positive cells were escalated in all human cancer cell lines, especially in the H1299 cells, treated with the extracts comparison to their untreated controls, referring that the strong cytotoxic effects of the bulb extracts towards cancer cells are mediated by induction of apoptosis. Lanosterol glycosides, named scillasaponins E-G, were isolated from $M$. paradoxum bulb extract, and these isolated compounds exhibited cytotoxic activity against HSC-2 human oral squamous cell carcinoma cells with IC $_{50}$ values ranging from 6.3 to $59 \mathrm{mg} / \mathrm{mL}$ when etoposide (positive control) had an $\mathrm{IC}_{50}$ value of $24 \mathrm{mg} / \mathrm{mL}$ (Ori et al., 2003). It can be concluded that the high amounts of saponins in the bulbs of $M$. muscarimi may result in cytotoxic activity.

\section{Conclusion}

In conclusion, this study is the first research that describes the potential antiproliferative and apoptotic efficacy on the cancer cells of M. muscarimi, which is an endemic and endangered geophyte species for Turkey. Further phytochemical and biological studies are needed to state the active constituents of $M$. muscarimi.

\section{Acknowledgments}

We would like to thank Busra Donmez and Sirin Ozturk who were members of the Secondary Metabolites Lab., (Pamukkale University) for assistance with the studies and would also like to extend particular thanks to Onur Tokgun and Aydin Demiray for their valuable support during the experiments in the Medical Biology Lab., Pamukkale University, Turkey. 


\section{References}

Abotaleb M, Samuel SM, Varghese E, Varghese S, Kubatka P, Liskova A and Büsselberg D. 2019. Flavonoids in Cancer and Apoptosis. Cancers (Basel), 11: 28.

Adebayo JO and Krettli AU. 2011. Potential antimalarials from Nigerian plants: a review. J Ethnopharmacol, 133: 289-302.

Adinolfi M, Barone G, Belardini M, Lanzetta R, Laonigro G and Parrilli M. 1985. Homoisoflavanones from Muscari comosum bulbs. Phytochemistry, 24: 2423-2426.

Balakrishnan N, Panda AB, Raj NR, Shrivastava A and Prathani RB. 2009. The evaluation of nitric oxide scavenging activity of Acalypha indica Linn Root. Asian J Res Chem, 2: 148-150.

Bray F, Ferlay J, Soerjomataram I, Siegel RL, Torre LA and Jemal A. 2018. Global cancer statistics 2018: GLOBOCAN estimates of incidence and mortality worldwide for 36 cancers in 185 countries. CA Cancer J. Clin, 68: 394-424.

Eker I. 2019. Muscari fatmacereniae (Asparagaceae, Scilloideae), a new species from southern Anatolia, Phytotaxa, 397: 99-106.

Eroğlu Özkan E, Demirci Kayıran S, Taşkın T and Abudayyak M. 2018. In vitro antioxidant and cytotoxic activity of Muscari neglectum growing in Turkey. Marmara Pharm J, 22: 74-79.

Fulda S. 2010. Modulation of apoptosis by natural products for cancer therapy. Planta Med, 76: 1075-1079.

Hanahan D and Weinberg RA. 2011. Hallmarks of cancer: the next generation. Cell, 144: 646-674.

Hiai S, Oura H and Nakajima T. 1976. Color reaction of some sapogenins and saponins with vanillin and sulfuric acid. Planta Med, 29: 116-122.

Hoekstra JM, Boucher TM, Ricketts TH and Roberts C. 2005. Confronting a biome crisis: global disparities of habitat loss and protection. Ecol. Lett, 8: 23-29.

Kayıran SD and Özkan EE. 2017. The ethnobotanical uses of Hyacinthaceae species growing in Turkey and a review of pharmacological activities. Indian J Tradit Know, 16: (2017) 243250 .

Lim TK. 2014. Muscari neglectum. Edible Medicinal And NonMedicinal Plants. Springer Netherlands 122.

Loizzo MR, Tundis R and Menichini F. 2010. Chelating, antioxidant and hypoglycaemic potential of Muscari comosum (L.) Mill. bulb extracts. Int J Food Sci Nutr, 61: 780-791.

Lourenço SC, Moldão-Martins M and Alves VD. 2019. Antioxidants of Natural Plant Origins: From Sources to Food Industry Applications. Molecules, 24: 4132.

Mammadov R, Ili P and Dusen O. 2012. Phenolic contents and antioxidant properties of Muscari parviflorum Desf. J. Chem. Soc. Pak, 34: 651-655.

Mammadov R, Ozay C, Dusen O, Aydin C, Yaka H and Dusen S. 2016. Evaluation of antioxidant, antimicrobial and cytotoxic activities of Muscari muscarimi Medik. bulb and flower extracts from Turkey. Fresenius Environ Bull, 25: 1680-1685.

Man S, Gao W, Zhang Y, Huang L and Liu C. 2010. Chemical study and medical application of saponins as anti-cancer agents. Fitoterapia, 81: 703-714.

Miadokova E, Masterova I, Vlckova V, Duhova V and Toth J. 2002. Antimutagenic potential of homoisoflavonoids from Muscari racemosum. J Ethnopharmacol, 81: 381-386.
Mulholland DA, Schwikkard SL and Crouch NR. 2013. The chemistry and biological activity of the Hyacinthaceae. Nat Prod Rep, 30: 1165-1210.

Moreno MI, Isla MI, Sampietro AR and Vattuone MA. 2000. Comparison of the free radical-scavenging activity of propolis from several regions of Argentina. J Ethnopharmacol, 71: 109114.

Ori K, Koroda M, Mimaki Y, Sakagami H and Sashida Y. 2003. Lanosterol and tetranorlanosterol glycosides from the bulbs of Muscari paradoxum. Phytochemistry, 64: 1351-1359.

Ozay C and Mammadov R. 2017. Screening of some biological activities of Alyssum fulvescens var. fulvescens known as Ege madwort. Acta Biol Hung, 68: 310-320.

Ozel CA, Khawar KM and Unal F. 2015. Factors affecting efficient in vitro micropropagation of Muscari muscarimi Medikus using twin bulb scale. Saudi J Biol Sci, 22: 132-138.

Oztas H, Oztas F, Aladag MO and Alas A. 2018. An Endemic Plant of Ermenek Region (Turkey), Muscari muscarimi: Economic Importance, and Is There a Useful Way Out Cultivation in Its Natural Habitats? JFSE, 8: 189-190.

Pandey MK, Prasad S, Tyagi AK, Deb L, Huang J, Karelia DN, Amin SG and Aggarwal BB. 2016. Targeting cell survival proteins for cancer cell death. Pharmaceuticals, 9: 11.

Prieto P, Pineda M and Aguilar M. 1999. Spectrophotometric quantitation of antioxidant capacity through the formation of a phosphormolybdenum complex: specific application to the determination of vitamin E. Anal Biochem, 269: 337-341.

Ravishankar D, Rajora AK, Greco F and Osborn HMI. 2013. Flavonoids as prospective compounds for anti-cancer therapy. Int. J. Biochem. Cell Biol, 45: 2821-2831.

Re R, Pellegrini N, Proteggente A, Pannala A, Yang M and RiceEvans C. 1999. Antioxidant activity applying an improved ABTS radical cation decolorization assay. Free Radic Biol Med, 26: 1231-1237.

Shahidi and Ambigaipalan P. 2015. Phenolics and polyphenolics in foods, beverages and spices: antioxidant activity and health effects-a review. J. Funct. Foods, 18: 820-897.

Tungmunnithum D, Thongboonyou A, Pholboon A and Yangsabai A. 2018. Flavonoids and Other Phenolic Compounds from Medicinal Plants for Pharmaceutical and Medical Aspects: An Overview. Medicines, 5: 93.

Urbancikova M, Masterova I and Toth J. 2002. Estrogenic/antiestrogenic activity of homoisoflavonoids from bulbs of Muscari racemosum (L.) Miller. Fitoterapia, 73: 724726.

Vrancheva R, Popova A, Mihaylova D and Krastanov A. 2020. Phytochemical Analysis, In Vitro Antioxidant Activity and Germination Capability of Selected Grains and Seeds. Jordan J Biol Sci, 13: 337-342.

Zengin G and Aktumsek A. 2014. Investigation of Antioxidant Potentials of Solvent Extracts from Different Anatomical Parts of Asphodeline anatolica E. Tuzlaci: an Endemic Plant to Turkey. Afr J Tradit Complement Altern Med, 11: 481-488.

Zengin G, Nithiyanantham S, Locatelli M, Ceylan R, Uysal S, Aktumsek A, Selvi PK and Maskovic P. 2015. Screening of in vitro antioxidant and enzyme inhibitory activities of different extracts from two uninvestigated wild plants: Centranthus longiflorus subsp. longiflorus and Cerinthe minor subsp. auriculata. Eur J Integr Med, 8: 286-292. 